\title{
FAKTOR-FAKTOR YANG MEMENGARUHI NIAT MENGGUNAKAN KECAP LOKAL
}

\author{
S. Berto Fready Siahaan ${ }^{1}$, Ujang Sumarwan ${ }^{2}$, Dodik Ridho Nurrochmat ${ }^{3}$ \\ ${ }^{1}$ Program Pascasarjana Manajemen dan Bisnis, Institut Pertanian Bogor, Bogor 16151, Indonesia \\ ${ }^{2}$ Departemen IImu Keluarga dan Konsumen, Fakultas Ekologi Manusia, Institut Pertanian Bogor, \\ Bogor 16680, Indonesia \\ ${ }^{3}$ Direktorat Kajian Strategis dan Kebijakan Pertanian, Institut Pertanian Bogor, \\ Bogor 16680, Indonesia \\ *)Email: siahaan.berto@gmail.com
}

\begin{abstract}
Abstrak
Penelitian ini bertujuan untuk menganalisis faktor-faktor yang memengaruhi niat pedagang makanan dalam menggunakan kecap lokal bagi produk makanan yang dibuatnya. Penelitian ini menggunakan pendekatan perilaku terencana (theory of planned behavior) yang memandang niat sebagai pendorong utama untuk terjadinya suatu perilaku tertentu. Penelitian dilakukan di wilayah Bogor dengan responden pedagang makanan yang pernah atau sedang menggunakan kecap lokal. Pengumpulan data dilakukan dengan wawancara tatap muka terhadap 102 responden menggunakan kuesioner. Pengolahan data dilakukan dengan metode deskriptif dan uji regresi linear berganda. Hasil penelitian menunjukkan bahwa sikap terhadap perilaku $\left(A_{a c t}\right)$ dan kontrol perilaku (PBC) merupakan komponen yang signifikan memengaruhi niat untuk menggunakan kecap lokal, sedangkan komponen norma subjektif (SN) tidak berpengaruh secara signifikan. Berdasarkan hasil penelitian, faktor-faktor yang memengaruhi niat menggunakan kecap lokal adalah memberi keuntungan, membuat masakan menjadi sedap, membawa kesejahteraan bagi masyarakat lokal, harga yang terjangkau, mutu yang baik, dan kemudahan diperoleh.
\end{abstract}

Kata kunci: kecap lokal, niat, pedagang makanan, teori perilaku terencana

\section{Determinant Factors of Intention for Using The Traditional Soy Sauces}

\begin{abstract}
The purpose of this research was to analyze the determinant factors of intention of the food sellers in using the traditional soy sauces for their products. The theory of planned behavior (TPB) was used as approach to explaine the intention as the major causal for the occurrence of a certain behavior. The research was conducted in Bogor and involved the food sellers who were using the traditional soy sauces. The data collection was conducted by personal interview of 102 respondents using quesionairres. The data was processed by the descriptive and the multiple linear regression methods. The result showed that the attitude toward behavior ( $A_{\text {act }}$ ) and the perceived behavioral control (PBC) significantlyaffected the intention, while the subjective norm (SN) did not significantly affect the intention. Based on the result, the determinant factors of intention for using the traditional soy sauces were creating of profit, creating of food deliciousness, creating of welfare for local communities, accceptable price, good quality, and easiness to get.
\end{abstract}

Keywords: food seller, intention, theory of planned behavior, traditional soy sauce

\section{PENDAHULUAN}

Kecap adalah produk olahan dari kedelai yang dibuat dengan cara fermentasi, memiliki tekstur cair untuk rasa asin atau kental untuk rasa manis, berwarna coklat kehitam-hitaman serta mempunyai rasa dan aroma yang khas (Purwoko \& Handayani, 2007; Setiawati, 2008). Kecap juga dapat menghasilkan antioksidan alami sehingga membuat produk ini baik untuk kesehatan (Dedin, Apriyantono, \& Andarwulan, 2006). Kedelai merupakan salah satu komoditas yang menjadi target swasembada pangan disamping jagung dan padi. Kemajuan dalam industri kecap sebagai produk hilir dari kedelai akan mendorong kegairahan petani untuk menanam kedelai dikarenakan adanya permintaan yang meningkat dari industri.

Industri kecap merupakan salah satu industri pangan yang populer. Produk kecap tersebar merata di seluruh Indonesia dan keberadaannya relatif cukup lama, misalnya kecap Benteng $\mathrm{SH}$ yang didirikan pada tahun 
1920 di Tangerang Banten, kecap Zebra di Bogor yang ada sejak 1945, juga kecap Laron di Tuban yang berproduksi sejak $1945^{1}$. Produsen kecap umumnya dimulai dengan skala kecil sebagai industri rumah tangga yang diproses secara tradisional dan mempunyai area pemasaran yang terbatas. Saat ini, sebagian dari produsen kecap telah berkembang menjadi produsen skala besar, dengan proses yang lebih modern serta pemasaran yang luas mencapai wilayah nasional seperti kecap Bango (Unilever) dan kecap ABC (Heinz ABC). Meskipun begitu, masih banyak perusahaan kecap yang masih tetap "setia" pada skala daerah (lokal) seperti merek-merek yang disebut di atas (Rosa, 2010).

Sebuah tulisan menarik berjudul $^{1}$ "Perkecapan: Tiada Loyalitas Seperti Penikmat Kecap" mengangkat adanya persaingan yang tidak imbang antara kecap keluaran pabrik besar dengan kecap yang diproduksi secara rumahan (kecap lokal). Dalam tulisan tersebut disebutkan bahwa meskipun aneka kecap keluaran pabrik besar telah beredar luas, puluhan kecap lokal yang sebagian diproduksi secara rumahan sampai sekarang tetap bertahan. Basis pertahanan mereka terletak pada penggemarnya yang amat loyal. Loyalitas para konsumen tersebut sebagian besar didasarkan pada kualitas rasa.

Banyak penelitian tentang kecap telah dilakukan namun sebagian besar berfokus pada merek-merek kecap populer seperti Bango, ABC, Sedaap, Indofood dan lainnya. Hal tersebut dapat dipahami mengingat salah satu alasannya adalah adanya dukungan dari perusahaan dalam rangka riset pasar. Pada penelitian lain, kebanyakan respondennya adalah kelompok rumah tangga (Quantrianto, Hutomo, \& Pujiarti, 2013). Penelitian tentang kecap lokal (tradisional) pernah dilakukan pada tahun 2010 yang mana fokus penelitiannya adalah manajemen strategik dari institusi perusahaan kecap tersebut (Rosa, 2010).

Penelitian terhadap konsumen tidak langsung seperti pedagang makanan belum banyak dilakukan. Pedagang makanan adalah satu dari beberapa segmen dalam pemasaran kecap. Pedagang makanan adalah segmen yang potensial berkontribusi bagi keberlangsungan bisnis karena terkait dengan pemakaian yang relatif besar dan berkelanjutan dibandingkan dengan segmen rumah tangga. Kesuksesan penjualan makanan yang

\footnotetext{
${ }^{1}$ Kompas Minggu, 6 April 2014
}

menggunakan kecap akan meningkatkan dan menjaga keberlanjutan pembelian kecap. Oleh karena itu, penting untuk menjadikan pedagang makanan sebagai responden dalam penelitian tentang kecap lokal.

Teori perilaku terencana yang dikembangkan oleh Ajzen (1991) menjelaskan bahwa niat perilaku merupakan kondisi yang paling dekat untuk meramalkan perilaku tertentu. Adanya niat perilaku yang kuat akan mendorong seseorang untuk mewujudkan perilaku yang diinginkannya (Ajzen, 1991). Teori perilaku terencana menjelaskan bahwa faktor utama yang memengaruhi perilaku seseorang adalah niatnya atau kecenderungannya untuk melakukan tindakan tersebut (Sumarwan, 2011). Astuti dan Hartoyo (2013) dalam hasil penelitiannya mengenai sikap terhadap perencanaan keuangan hari tua menemukan bahwa sikap dan kontrol perilaku berpengaruh terhadap niat untuk melakukan perencanaan keuangan pada hari tua. Niat perilaku adalah keinginan dari individu untuk melakukan suatu perilaku tertentu (Lee \& Mok, 2013). Melalui pengujian niat berperilaku dapat diketahui faktor-faktor yang mendasari konsumen dalam memilih dan menggunakan produk. Pengetahuan tentang faktor-faktor dari niat penting dalam pemasaran. Pemahaman tentang faktor-faktor tersebut berguna bagi penyusunan strategi pemasaran yang meliputi 4P's: Product, Price, Place, dan Promotion.

Berdasarkan uraian tersebut, penelitian ini bertujuan untuk menganalisis pengaruh sikap terhadap perilaku, norma-norma subjektif dan kontrol perilaku terhadap niat menggunakan kecap lokal, serta menganalisis faktor-faktor yang memengaruhi niat menggunakan kecap lokal.

\section{METODE}

Penelitian ini menggunakan desain cross sectional. Lokasi penelitian dipilih secara purposive yaitu wilayah Bogor (wilayah administratif Kabupaten dan Kota Bogor). Pengambilan data penelitian dilakukan pada bulan November 2014 sampai Januari 2015.

Populasi pada penelitian ini adalah pedagang makanan yang berjualan di wilayah Bogor. Contoh dalam penelitian ini berjumlah 102 orang yang ditentukan secara purposive, yaitu pedagang makanan yang sedang atau pernah menggunakan kecap lokal untuk produk yang dijualnya. Kecap lokal yang dimaksud adalah merek kecap manis dengan kriteria sebagai berikut: (1) proses pembuatannya 
dilakukan secara tradisional, (2) aktivitas promosi dilakukan secara terbatas, artinya tidak dipromosikan pada media nasional, dan (3) jaringan distribusinya terbatas, dalam hal ini secara umum tidak dipasarkan di pusat perbelanjaan modern.

Penelitian ini menggunakan data primer yaitu karakteristik usaha, karakteristik responden, perilaku penggunaan kecap dan dimensi teori perilaku terencana. Pengumpulan data dilakukan dengan wawancara tatap muka menggunakan kuesioner. Karakteristik usaha terdiri atas kepemilikan usaha, omzet per hari dan lama usaha. Karakteristik responden terdiri atas usia, jenis kelamin dan pendidikan. Usia responden dikategorikan berdasarkan rentang puluhan. Jenjang pendidikan diukur berdasarkan jenjang pendidikan formal yang ditempuh responden. Perilaku penggunaan kecap terdiri atas jumlah pemakaian kecap per hari, jenis kemasan yang dibeli serta tempat pembelian kecap.

Sementara itu, dimensi teori perilaku terencana yang diukur mencakup sikap, norma subjektif, dan kontrol perilaku. Sikap terhadap perilaku diukur dengan enam pertanyaan yang terdiri atas tiga pertanyaan untuk mengukur keyakinan dan tiga pertanyaan untuk mengukur evaluasi. Norma subjektif yang diukur dalam penelitian ini adalah keyakinan normatif (2 pertanyaan) dan motivasi mematuhi (2 pertanyaan). Kontrol perilaku diukur dengan enam pertanyaan yang terdiri atas keyakinan kontrol tiga pertanyaan dan kekuatan faktor kontrol tiga pertanyaan. Pilihan jawaban dalam instrumen sikap, norma subjektif, dan kontrol perilaku terdiri atas sangat tidak setuju (skor 1), tidak setuju (skor 2), netral (skor 3), setuju (skor 4) dan sangat setuju (skor 5). Niat menggunakan kecap lokal diukur dengan satu pertanyaan dengan pilihan jawaban dalam instrumen niat terdiri atas sangat tidak setuju (skor 1), tidak setuju (skor 2), netral (skor 3), setuju (skor 4) dan sangat setuju (skor 5).

Instrumen yang digunakan telah valid dan reliabel dengan nilai korelasi antara (r-product momment) antara 0,375-0,867 (r-tabel=0,195) dan Cronbach's alpha sebesar 0,918. Data yang diperoleh diolah melalui proses pengeditan, pengodean, penilaian, pemasukan, dan analisis data. Analisis data yang digunakan dalam penelitian ini adalah analisis deskriptif dan uji regresi linear berganda. Uji regresi linear berganda digunakan untuk menganalisis pengaruh sikap, norma subjektif dan kontrol perilaku terhadap niat menggunakan kecap lokal.

\section{HASIL}

\section{Karakteristik Usaha}

Mayoritas responden adalah pemilik dari usaha $(70,0 \%)$ dan sisanya $(30,0 \%)$ merupakan orang yang dipekerjakan (karyawan). Sebanyak 75 persen responden mempunyai omzet per hari kurang dari 500 ribu rupiah dan sisanya $(25,0 \%)$ lebih dari 500 ribu rupiah, artinya mayoritas responden adalah pedagang makanan skala kecil. Mayoritas responden menjalani usaha bisnisnya lebih dari 5 tahun $(55,0 \%)$, disusul oleh kelompok yang telah menjalankan usahanya antara 2 sampai 5 tahun $(25,0 \%)$ dan terakhir kelompok yang kurang dari 2 tahun (20,0\%). Dengan demikian berdasarkan karakteristik jenis usaha, mayoritas responden merupakan pemilik usaha dengan skala kecil dan telah menjalankan usahanya dalam waktu yang relatif lama.

\section{Karakteristik Demografi Responden}

Responden terbanyak berada pada usia 30 - 39 tahun $(32,0 \%)$, diikuti usia 40-49 tahun $(24,0 \%)$ dan 20-29 tahun (21,0\%). Proporsi jumlah responden adalah pria $(75,0 \%)$ lebih banyak dibandingkan wanita $(25,0 \%)$. Secara keseluruhan $(97,0 \%)$ responden berada pada rentang pendidikan SD sampai SLTA. Persentase responden dengan pendidikan SD $(35,0 \%)$ sedikit lebih besar dari SLTP $(31,0 \%)$ dan SLTA $(31,0 \%)$.

\section{Perilaku Penggunaan Kecap}

Mayoritas responden (77,0\%) adalah kelompok yang mengonsumsi kecap kurang dari 2 kemasan $600 \mathrm{ml}$, sebagian responden $(23,0 \%)$ mengonsumsi kecap antara 2 sampai 5 kemasan, dan tidak satupun responden yang menggunakan kecap lebih dari 5 kemasan. Sebanyak 61 persen responden menyukai membeli kecap dalam bentuk kemasan isi ulang, 37 persen dalam kemasan botol dan terdapat 2 persen dalam kemasan jerigen.

Kemasan isi ulang menjadi pilihan terbanyak, hal itu menggambarkan bahwa umumnya responden memilih kemasan dengan harga yang lebih hemat tanpa harus terbebani pembelian volume besar seperti pada kemasan jerigen.

Sementara itu, tempat membeli kecap yang disukai adalah di pasar $(59,0 \%)$ diikuti responden yang memilih membeli kecap di toko terdekat (39,0\%). Pada umumnya membeli kecap di pasar lebih menguntungkan karena 
ketersediaan penjualnya yang banyak serta ada peluang untuk memperoleh harga yang lebih murah dengan cara membandingkan harga dari satu toko dengan toko lainnya.

\section{Pengaruh Sikap terhadap Perilaku, Norma Subjektif dan Kontrol Perilaku terhadap Niat Menggunakan Kecap Lokal}

Fishbein dan Ajzen (2010) menjelaskan bahwa komponen pertama dari teori perilaku terencana adalah sikap terhadap perlaku $\left(A_{a c t}\right)$. Sikap merefleksikan evaluasi secara keseluruhan terhadap perilaku. Sikap seseorang terhadap tingkah laku tertentu merupakan hasil dari dua faktor, yaitu keyakinan seseorang tentang tingkah laku tertentu dan evaluasi atau tingkat konsekuensi dari perilaku tersebut. Komponen kedua adalah norma subjektif (SN) yang merupakan elemen sosial, yaitu keyakinan seseorang tentang apa yang orang lain pikir seharusnya ia lakukan, serta kekuatan motivasi seseorang untuk mematuhi harapan (norma) tersebut. Norma subjektif terdiri dari dua elemen, yaitu kepercayaan normatif yakni kepercayaan tentang apa yang orang lain ingin konsumen lakukan dan motivasi untuk memenuhi ekspektasi dari orang lain tersebut. Komponen ketiga adalah kontrol perilaku yang dirasakan (PBC). Kontrol perilaku ini merupakan kemampuan untuk berperilaku tertentu yang dipersepsikan oleh konsumen, atau dapat dinyatakan sebagai kontrol perilaku nonmotivasional yang dirasakan. Ketiga komponen tersebut berkombinasi untuk menentukan intensi (niat) seseorang dalam berperilaku.

Hasil pengolahan data berdasarkan perkalian unsur untuk setiap komponen dari teori perilaku terencana diperoleh nilai skor yang dapat diurutkan sebagai berikut: (1) Skor tertinggi dimiliki oleh komponen kontrol perilaku (PBC) yaitu keyakinan kontrol dan kekuatan faktor kontrol, (2) komponen sikap terhadap perilaku $\left(A_{a c t}\right)$ yaitu keyakinan perilaku dan evaluasi konsekuensi, (3) komponen norma subjektif (SN) dengan keyakinan normatif dan motivasi mematuhi memperoleh skor terkecil. Tabel 1 menunjukkan bahwa sikap terhadap perilaku (Aact) mempunyai tingkat kontribusi yang sedang, norma subjektif (SN) tingkat kontribusinya rendah dan kontrol perilaku (PBC) mempunyai tingkat kontribusi tinggi dalam membentuk niat berperilaku menggunakan kecap lokal.

Pertanyaan 1 pada Tabel 1 untuk komponen sikap terhadap perilaku adalah indikator bahwa menggunakan kecap lokal menguntungkan dengan skor 18,36 (tinggi), pertanyaan 2 bahwa kecap lokal membuat makanan menjadi sedap dengan skor 18,72 (tinggi) dan pertanyaan 3 bahwa kecap lokal mendatangkan kesejahteraan masyarakat lokal dengan skor 7,75 (rendah). Berdasarkan hasil tersebut maka urutan indikator dari sikap terhadap perilaku dalam berkontribusi membentuk niat adalah membuat makanan menjadi sedap, menguntungkan, dan mendatangkan kesejahteraan masyarakat lokal. Sementara itu, pertanyaan 1 pada Tabel 1 untuk komponen norma subjektif adalah indikator anjuran keluarga skor 5,08 (rendah), pertanyaan 2 anjuran teman skor 10,63 (rendah). Oleh karenanya, urutan indikator dari norma subjektif adalah anjuran teman kemudian anjuran keluarga. Pertanyaan 1 pada Tabel 1 untuk komponen kontrol perilaku adalah indikator harga dengan skor 16,99 (tinggi), pertanyaan 2 indikator mutu dengan skor 18,40 (tinggi), dan pertanyaan 3 indikator kemudahan diperoleh dengan skor 15,64 (tinggi). Oleh karenanya, urutan indikator dari kontrol perilaku dalam berkontribusi membentuk niat, yaitu mutu, harga, dan kemudahan diperoleh.

Tabel 1 Tingkat kontribusi dari masing-masing komponen dalam membentuk niat menggunakan kecap lokal

\begin{tabular}{|c|c|c|c|c|c|c|c|c|c|}
\hline \multirow{2}{*}{$P$} & \multicolumn{3}{|c|}{ Perilaku } & \multicolumn{3}{|c|}{ Norma subjektif } & \multicolumn{3}{|c|}{ Kontrol perilaku } \\
\hline & $b_{i}$ & $e_{i}$ & $b_{i} \times e_{i}$ & $\mathrm{r}_{\mathrm{i}}$ & $\mathrm{m}_{\mathrm{i}}$ & $r_{i} \times m_{i}$ & $\mathrm{p}_{\mathrm{i}}$ & $\mathrm{Ci}_{\mathrm{i}}$ & $\mathrm{p}_{\mathrm{i}} \times \mathrm{C}_{\mathrm{i}}$ \\
\hline 1 & 4,08 & 4,50 & 18,36 & 2,26 & 2,25 & 5,08 & 4,47 & 3,80 & 16,99 \\
\hline 2 & 4,17 & 4,49 & 18,72 & 3,28 & 3,24 & 10,63 & 4,25 & 4,33 & 18,40 \\
\hline 3 & 3,15 & 2,46 & 7,75 & & & & 3,93 & 3,98 & 15,64 \\
\hline \multirow{2}{*}{\multicolumn{2}{|c|}{$\begin{array}{l}\text { Rata-rata } \\
\text { Tingkat kontribusi (Interval) }\end{array}$}} & \multicolumn{2}{|c|}{14,94} & \multicolumn{3}{|c|}{7,86} & \multicolumn{3}{|c|}{17,01} \\
\hline & & \multicolumn{2}{|c|}{$\begin{array}{c}\text { Sedang } \\
(10,7-15,4)\end{array}$} & \multicolumn{3}{|c|}{$\begin{array}{c}\text { Rendah } \\
(5,9-10,6)\end{array}$} & \multicolumn{3}{|c|}{$\begin{array}{c}\text { Tinggi } \\
(15,5-20,2)\end{array}$} \\
\hline
\end{tabular}

Keterangan:

$\mathrm{P}^{*}=$ Nomor urut pertanyaan, $\mathrm{b}_{\mathrm{i}}=$ Keyakinan perilaku, $\mathrm{e}_{\mathrm{i}}=$ Evaluasi konsekuensi, $\mathrm{r}_{\mathrm{i}}=$ Keyakinan normatif, $\mathrm{m}_{\mathrm{i}}=$ Motivasi mematuhi, $\mathrm{c}_{\mathrm{i}}=$ Kekuatan control, $\mathrm{p}_{\mathrm{i}}=$ Keyakinan kontrol 
Tabel 2 Koefisien uji regresi linear berganda pengaruh sikap, norma subjektif, dan kontrol perilaku terhadap niat menggunakan kecap lokal

\begin{tabular}{llccr}
\hline Variabel & Koef. & Sig. & T & VIF \\
\hline Konstanta & 0,351 & 0,259 & 1,135 & \\
Aact & 0,054 & 0,000 & 6,428 & 2,695 \\
SN & 0,008 & 0,201 & 1,288 & 2,149 \\
PBC & 0,023 & 0,004 & 2,988 & 2,382 \\
\hline F & & & 82,461 \\
R $^{2}$ & & & & 0,846 \\
Adjusted R Square & & & 0,716 \\
\hline
\end{tabular}

Tabel 2 menyajikan koefisien uji regresi linear berganda pengaruh sikap, norma subjektif, dan kontrol perilaku terhadap niat menggunakan kecap lokal. Melalui proses pengujian regresi linear, diperoleh persamaan: $Y=0,351+0,054 A_{a c t}+0,008 S N+0,023 P B C$, dengan nilai signifikansi dari variabel $S N$ sebesar 0,201 (lebih besar dari 0,05), sedangkan kedua variabel lainnya yaitu $A_{\text {act }}$ sebesar 0,000 dan PBC sebesar 0,004 (lebih kecil dari 0,05). Hasil uji selengkapnya dapat dilihat pada Tabel 2.

Nilai signifikansi dari konstanta pada persamaan di atas adalah 0,259 yang lebih besar dari 0,05 artinya angka konstanta sebesar 0,351 tersebut tidak berdampak signifikan terhadap pembentukan niat. Nilai koefisien dari sikap terhadap perilaku (Aact) adalah 0,054 dengan signifikansi 0,000 (lebih kecil dari 0,05 ) yang berarti setiap peningkatan satu satuan faktor sikap terhadap perilaku akan memberikan kontribusi pada niat sebesar 0,054 poin. Nilai koefisien dari norma subjektif (SN) adalah 0,008 dengan signifikansi 0,201 (lebih besar dari 0,05) berarti komponen norma subjektif tidak berkontribusi secara signifikan. Sementara itu, nilai koefisien dari kontrol perilaku (PBC) sebesar 0,023 dengan signifikansi 0,004 (lebih kecil dari 0,05) berarti setiap peningkatan satu satuan kontrol perilaku akan berkontribusi pada niat menggunakan kecap lokal sebesar 0,023 poin.

Nilai $F$ dalam Anova adalah sebesar 82,461 yakni lebih besar dari nilai tabel untuk taraf signifikan 5 persen yaitu 3,94 yang berarti kedua komponen TPB tersebut secara bersama-sama memberikan pengaruh yang signifikan terhadap variabel bebasnya (niat). Dalam hasil uji regresi linear berganda yang dilakukan diperoleh nilai Adjusted $\mathrm{R}$ Square sebesar 0,716 yang berarti niat untuk menggunakan kecap lokal dapat dijelaskan faktor-faktor dalam perilaku terencana sebesar 71,6 persen, sementara sisanya 28,4 persen adalah oleh faktor-faktor lainnya yang tidak diteliti.

Nilai VIF dari komponen $A_{\text {act }}$ adalah 2,695, komponen SN 2,149 dan komponen PBC 2,382. Hal tersebut menunjukkan bahwa nilai VIF seluruh komponen adalah lebih kecil dari 5,0 sehingga dinyatakan bahwa tidak terjadi multikolinearitas pada persamaan yang terbentuk. Nilai $t$ pada $A_{\text {act }}$ adalah 6,428, sementara untuk SN adalah 1,288 dan PBC adalah 3,482, sedangkan nilai t tabel untuk signifikansi 5 persen adalah 1,900, berarti $A_{a c t}$ dan PBC mempunyai nilai $t$ hitung yang lebih besar dari $t$ tabel sehingga dinyatakan bahwa komponen $A_{a c t}$ dan PBC secara sendiri-sendiri memberikan pengaruh yang signifikan terhadap variabel bebasnya (niat menggunakan kecap lokal), sedangkan nilai $\mathrm{t}$ hitung $\mathrm{SN}$ lebih kecil dari $\mathrm{t}$ tabel, dengan demikian komponen $\mathrm{SN}$ secara sendiri juga tidak berkontribusi secara signifikan dalam membentuk niat perilaku menggunakan kecap lokal.

\section{PEMBAHASAN}

Pedagang makanan yang menggunakan kecap sebagai bahan penyedap masakannya cukup banyak dijumpai karena kecap merupakan bahan makanan yang populer di masyarakat (Dedin, Apriyantono, \& Andarwulan, 2006). Hanya saja, keberadaan pedagang makanan pengguna kecap lokal bersifat sporadis (tidak merata) sehingga responden yang diperoleh tidak dapat mewakili seluruh wilayah yang dicakup (Kabupaten dan Kota Bogor). Oleh karena itu hasil penelitian ini terbatas pada persepsi dari responden yang dianalisis.

Niat merupakan kondisi yang paling dekat untuk meramalkan perilaku tertentu. Niat yang kuat akan mendorong seseorang untuk mewujudkan perilaku yang diinginkannya (Ajzen, 1991). Memahami niat konsumen untuk menggunakan kecap lokal adalah penting bagi produsen untuk memastikan bahwa produknya akan terus digunakan, dengan demikian usahanya akan dapat terus dipertahankan bahkan dikembangkan.

Berdasarkan karakteristik usaha, pemakai kecap lokal (pernah atau sedang menggunakan), hasil penelitian menunjukkan bahwa didominasi oleh pemilik usaha dengan omzet kurang dari Rp500.000 per hari dan telah menjalankan usahanya dalam waktu yang relatif lama. Hal ini berarti bahwa penggunaan kecap lokal lebih banyak diputuskan oleh pemilik usaha, kecap lokal sangat diperlukan 
oleh pedagang makanan dengan omzet kecil, dan banyak digunakan oleh pedagang yang telah lama berjualan. Dengan kata lain, konsumen atau pasar dari kecap lokal lebih banyak pada pedagang makanan yang merupakan pemilik usaha, dengan omzet yang kecil dan pedagang yang relatif sudah lama berjualan.

Pada karakteristik demografi responden, pemakai kecap lokal adalah pedagang makanan dengan rentang usia 20 sampai 49 tahun $(77 \%)$ yang merupakan usia produktif untuk berwirausaha (Tjiptoherijanto, 2001), dengan latar pendidikan SD sampai SMA (97\%). Latar belakang pendidikan tersebut mengambarkan bahwa pemakai kecap lokal adalah orang yang mempunyai latar belakang pendidikan formal untuk menjalankan unit usahanya yang sederhana.

Perilaku dari sebagian besar pemakai kecap lokal dalam penelitian ini menyukai pembelian dalam bentuk kemasan isi ulang karena lebih praktis dan hemat. Responden juga merupakan konsumen yang menyukai membeli kecap di pasar karena ketersediaan produknya yang beragam serta ada peluang untuk memperoleh harga yang lebih murah dengan cara membandingkan harga dari satu toko dengan toko lainnya. Pengetahuan tentang karakteristik konsumen serta perilakunya merupakan hal yang penting bagi produsen untuk menyusun strategi pemasaran produknya.

Berdasarkan pengolahan data dengan regresi linear berganda untuk menganalisis pengaruh komponen perilaku terencana terhadap niat menggunakan kecap lokal menunjukkan bahwa sikap terhadap perilaku $\left(A_{a c t}\right)$ dan kontrol perilaku (PBC) baik secara bersama-sama maupun sendiri memengaruhi secara signifikan terhadap niat untuk menggunakan kecap lokal. Hal ini berarti keputusan responden untuk berniat menggunakan kecap lokal ditentukan oleh dua komponen teori perilaku terencana tersebut yaitu sikap terhadap perilaku dan kontrol perilaku. Hal yang sama juga ditunjukkan dalam penelitian yang dilakukan oleh Gronhoj et al. (2012) yang menggunakan teori perilaku terencana untuk memprediksi niat mengonsumsi makanan sehat di kalangan penduduk dewasa di Denmark. Kontrol perilaku dan sikap terhadap perilaku berpengaruh positif terhadap niat mengonsumsi makanan sehat, sedangkan pengaruh sosial (norma subjektif) tidak berperan terhadap niat tersebut. Demikian juga dengan penelitian Saleki, Sayedsaleki, \&
Rahimi (2010) yang menganalisis perilaku membeli makanan organik dari konsumen di Iran. Pengetahuan tentang organik, kualitas dan harga berpengaruh positif terhadap niat membeli, sedangkan norma subjektif tidak berpengaruh signifikan. Hal tersebut menunjukkan bahwa niat dalam membeli atau menggunakan produk makanan cenderung ditentukan oleh sikap terhadap perilaku dan kontrol perilaku, sementara norma subjektif tidak berperan signifikan.

Hasil penelitian ini mengaskan bahwa peningkatan penilaian responden terhadap indikator-indikator dari sikap terhadap perilaku (menguntungkan, menyedapkan masakan dan membawa kesejahteraan masyarakat lokal) dan indikator-indikator kontrol perilaku (harga, mutu dan kemudahan diperoleh) akan meningkatkan niat responden untuk berperilaku menggunakan kecap lokal. Komponen norma subjektif tidak berpengaruh terhadap munculnya niat untuk menggunakan kecap lokal, artinya anjuran dari keluarga dan sesama pedagang tidak akan memengaruhi responden dalam mengambil keputusan untuk menggunakan kecap lokal.

Pengujian teori perilaku terencana (Theory of Planned Behavior) dengan metode regresi linear berganda diperoleh persamaan $Y=0,351$ $+0,054 A_{a c t}+0,008 S N+0,023 P B C$. Nilai konstanta sebesar 0,351 menunjukkan bahwa tanpa adanya pengaruh dari sikap terhadap perilaku $\left(A_{a c t}\right)$ dan kontrol perilaku (PBC) akan terdapat niat menggunakan kecap lokal sebesar 0,351 satuan. Hasil tersebut mengindikasikan bahwa pada responden sudah ada niat untuk menggunakan kecap lokal.

Dalam persamaan di atas, nilai koefisien sikap terhadap perilaku (Aact) 0,054 adalah lebih besar dari koefisien kontrol perilaku (PBC) 0,023 maupun SN 0,008 sehingga faktor sikap terhadap perilaku tersebut sebaiknya menjadi prioritas bilamana ingin meningkatkan niat menggunakan kecap lokal bagi segmen pedagang makanan. Namun yang terbaik adalah mengelola kedua faktor tersebut (sikap dan kontrol perilaku) karena akan menghasilkan pengaruh yang menyeluruh untuk peningkatan niat menggunakan kecap lokal.

Indikator yang tercakup dalam sikap terhadap perilaku $\left(A_{a c t}\right)$ adalah hal terkait keuntungan, menyedapkan dan kesejahteraan masyarakat lokal. Sementara itu, indikator yang tercakup dalam kontrol perilaku (PBC) adalah harga, mutu, dan kemudahan diperoleh. Pada sikap terhadap perilaku, skor tertinggi adalah 
indikator membuat masakan menjadi sedap, kemudian indikator memberi keuntungan, dan terakhir indikator mendatangkan kesejahteraan bagi masyarakat lokal. Sementara itu, pada kontrol perilaku, skor tertinggi adalah indikator mutu yang baik, kemudian indikator harga yang terjangkau, dan terakhir indikator kemudahan diperoleh.

Hasil ini sejalan dengan penelitian yang dilakukan oleh Jaafar, Lalp, \& Naba (2012) yang meneliti persepsi konsumen terhadap produk makanan produksi rumahan di Malaysia. Hasil penelitian tersebut menunjukkan bahwa atribut kualitas adalah yang utama, diikuti dengan atribut harga, lalu kemasan dan terakhir pengalaman membeli sebelumnya. Sumarwan, Johan, dan Anindita (2011) menjelas-kan dalam hasil penelitiannya bahwa niat beli produk dipengaruhi oleh sikap dan atribut rasa merupakan atribut penting yang menjadi pertimbangan anak dalam memilih produk makanan ringan. Hasil penelitian ini juga mendukung penelitian sebelumnya yang dilakukan oleh Barus (2008) yaitu jenis, kualitas, kesegaran dan kesesuaian harga merupakan faktor-faktor yang memengaruhi keputusan konsumen dalam membeli buahbuahan di Kota Medan.

Dengan demikian, keenam indikator tersebut merupakan faktor-faktor yang direkomendasikan untuk dijadikan objek bagi peningkatan niat menggunakan kecap lokal. Berdasarkan indikator pada dua komponen perilaku terencana yang berpengaruh signifikan terhadap niat, melalui penelitian ini diperoleh faktor-faktor yang mempengaruhi niat menggunakan kecap lokal oleh pedagang makanan adalah memberi keuntungan, membuat masakan menjadi sedap, mendatangkan kesejahteraan bagi masyarakat lokal, harga yang terjangkau, mutu yang baik, dan kemudahan diperoleh. Hasil penelitian menegaskan bahwa peningkatan keyakinan responden terhadap indikator-indikator dari sikap terhadap perilaku (memberi keuntungan, membuat masakan menjadi sedap, dan mendatangkan kesejahteraan masyarakat lokal) dan indikatorindikator dari kontrol perilaku (harga yang terjangkau, mutu yang baik, dan kemudahan diperoleh) akan meningkatkan niat responden untuk berperilaku menggunakan kecap lokal.

Penelitian ini juga menegaskan bahwa komponen norma subjektif tidak berpengaruh terhadap munculnya niat pedagang makanan untuk menggunakan kecap lokal. Artinya anjuran dari keluarga dan sesama pedagang tidak akan memengaruhi responden dalam mengambil keputusan untuk menggunakan kecap lokal.

\section{SIMPULAN DAN SARAN}

Hasil penelitian menunjukkan bahwa sikap terhadap perilaku $\left(\mathrm{A}_{\mathrm{act}}\right)$ dan kontrol perilaku (PBC) merupakan komponen teori perilaku terencana yang signifikan memengaruhi niat untuk menggunakan kecap lokal, sementara norma subjektif (SN) tidak memengaruhi niat secara signifikan. Berdasarkan hasil tersebut maka yang menjadi faktor-faktor yang memengaruhi niat menggunakan kecap lokal adalah indikator-indikator dari variabel sikap terhadap perilaku dan kontrol perilaku yaitu memberi keuntungan, membuat masakan menjadi sedap, mendatangkan kesejahteraan bagi masyarakat lokal, harga yang terjangkau, mutu yang baik, dan kemudahan diperoleh.

Berdasarkan hasil penelitian, produsen kecap lokal disarankan untuk meningkatkan sikap positif dan kemampuan konsumen terhadap penggunaan kecap lokal dengan cara membuat program-program yang dapat menciptakan keuntungan bagi konsumen (seperti bantuan revitalisasi tempat usaha, pemberian bonus), pengembangan cita rasa produk, harga yang kompetitif, peningkatan mutu serta jaminan kemudahan diperoleh (melalui perluasan jaringan distribusi dan kesinambungan suplai). Program tersebut perlu dilakukan sebagai upaya untuk meningkatkan niat para pedagang makanan dalam menggunakan kecap lokal.

\section{DAFTAR PUSTAKA}

Ajzen, I. (1991). The theory of planned behavior. Organizational Behavior and Human Decision Process, 50, 179-201.

Astuti, R. N., \& Hartoyo. (2013). Pengaruh nilai, tingkat pengetahuan, dan sikap terhadap perencanaan keuangan hari tua. Jurnal IImu Keluarga \& Konsumen, 6(2), 109118.

Barus, S. (2008). Analisis Sikap dan minat konsumen dalam membeli buah-buahan di Carefour Plaza Medan Fair dan Supermarket Brastagi, Medan (Tesis). Sekolah Pascasarjana Universitas Sumatera Utara, Medan.

Dedin, F. R., Apriyantono, A., \& Andarwulan, N. (2006). Isolasi dan Karakterisasi Melanoidin Kecap Manis dan Peranannya sebagai Antioksidan. Jurnal Teknologi dan Industri Pangan, 17(3), 204-213. 
Fishbein, M. \& Ajzen, I. (2010). Predicting and changing behavior: The Reasoned Action Approach. New York, US: Psycology Press.

Gronhoj, A., Bech-Larsen, T., Chan, K., \& Tsang, L. (2012). Using theory of planned behavior to predict healthy eating among danish adolescents. Health Education, 113(1), 4-17.

Jaafar, S. N., Lalp, P. E., \& Naba, M. M. (2012). Consumers' perceptions, attitudes and purchase intention towards private label foods products in Malaysia. Asian Journal of Business and Management Sciences, 2(8), 73-90.

Lee, A. Y. K. \& Mok, W. K. (2013). A case study on application of the theory of planned behavior: predicting physical activity of adolescents in Hongkong. Journal Community Medical Health Education, 3(5), 231.

Purwoko, T. \& Handayani, N. S. (2007). Kandungan protein kecap manis tanpa fermentasi moromi hasil fermentasi rhizopus orizae dan R. Oligosphorus. Biodiversitas, 8(2), 223-227.

Quantrianto, F. H. H., Hutomo, P. T. P., \& Pujiarti, E. S. (2013). Pengaruh brand awareness, brand association dan perceived quality terhadap loyalitas pelanggan kecap manis merek $A B C$ (Studi konsumen swalayan ADA siliwangi Semarang). Jurnal IImiah Dinamika Ekonomi dan Bisnis, 1(1), 89-101.
Rosa, H. E. S. (2010). Analisis manajemen manajemen strategi pada kecap zebra dalam menghadapi persaingan yang semakin kompetitif. Jurnal IImiah Ranggagading, 10(2), 131-139.

Saleki, Z. S., Seyedsaleki, S. M., \& Rahimi, M. R. (2012). Organic food purchasing behavior in Iran. International Journal of Business and Social Science, 3(13), 278285.

Setiawati, B. B. (2008). Penentuan komponen kualitas dan bahan baku optimal produk kecap organik berbasis offline quality control. Jurnal Ilmu-ilmu Pertanian, 4(1), 8-19.

Sumarwan, U. (2011). Perilaku konsumen, edisi ke-2. Bogor, ID: Ghalia Indonesia.

Sumarwan, U, Johan, I. R., \& Anindita, D. (2011). Sikap, preferensi, dan niat beli terhadap produk makanan ringan pada anak usia sekolah. Jurnal IImu Keluarga \& Konsumen, 4(1).

Tiada loyalitas seperti penikmat kecap. (2014, 6 April). Harian Kompas.

Tjiptoherijanto, P. (2001). Proyeksi penduduk, angkatan kerja, tenaga kerja, dan peran serikat pekerja dalam peningkatan kesejahteraan. Majalah Perencanaan Pembangunan, 23, 1-10. 